\title{
Growth and metal uptake capacity of microalgae under exposure to chromium
}

\author{
Sụ phát triển và khả năng hấp thu kim loại của vi tảo trong phơ nhiếm với \\ crôm \\ Research article
}

Thanh-Son Dao ${ }^{1 *}$, Nguyen-Hong-Son Le ${ }^{1}$, Minh-Tan Vo ${ }^{1}$, Thi-My-Chi Vo ${ }^{1}$, The-Huy Phan ${ }^{2}$, Thi-Nhu-Phuong Bui ${ }^{2}$

${ }^{1}$ Hochiminh City University of Technology, 268 Ly Thuong Kiet St., Dist. 10, Hochiminh City, Vietnam; ${ }^{2}$ Institute for Environment and Resources, 142 To Hien Thanh St., Dist. 10, Hochiminh City, Vietnam

\begin{abstract}
Microalgae play a key function in aquatic ecosystems. Their development and growth are strongly regulated by trace metals as essential elements. However, trace metals could cause negative effects when exceeding certain concentrations in the environment. In this study we tested the development and growth rate of two freshwater microalgae, the cyanobacterium Pseudanabeana mucicola and the green alga Pediastrum duplex, from Vietnam over the period of 14 days exposing to chromium $(\mathrm{Cr})$ at the concentrations up to $1,936 \mu \mathrm{g} \mathrm{L}^{-1}$. Besides, the $\mathrm{Cr}$ uptake and absorption by P. mucicola were evaluated over 7 days incubated in medium containing $422 \mu \mathrm{g} \mathrm{Cr} \mathrm{L}^{-1}$. The results showed that $\mathrm{Cr}$ at the concentrations up to $1,078 \mu \mathrm{g} \mathrm{L}^{-1}$ did not inhibit the development and growth rate of $P$. mucicola. Similarly, concentration of $224 \mu \mathrm{g} \mathrm{Cr} \mathrm{L}{ }^{-1}$ had no adverse effects on growth of $P$. $d u$ plex. The cyanobacterium $P$. mucicola could make a reduction up to $71 \%$ of $\mathrm{Cr}$ in the test medium, hence become a distinguished candidate for metal phytoremediation. To the best of our knowledge this is the first investigation on the responses and absorption of $\mathrm{Cr}$ by freshwater microalgae from Vietnam.
\end{abstract}

Vi tảo đóng vai trò quan trọng trong hệ sinh thái thủy vục. Sự sinh truởng và phát triển của chúng được điều tiết mạh mẽ bởi kim loại vi luợng nhu nhüng yếu tố thiết yểu. Tuy nhiên, nhũng kim loại vi luợng này có thể gây ra những ảnh hưởng tiêu cực khi vuợt quá nồng độ nhất định trong môi trường. Trong nghiên cứu này, chúng tôi thử nghiệm sự phát triển và tốc độ phát triển của hai loài vi tảo nuó́c ngot: loài tảo lam Pseudanabeana mucicola và loài tảo luc Pediastrum duplex có nguồn gốc tù̀ Việt Nam trong thời gian 14 ngày phơi nhiễm với crôm (Cr) tại nồng độ lên tới 1.936 $\mu g L^{-1}$. Bên cạnh đó, sụ háp thu Cr của P. mucicola cũng đã được đánh giá trong thời gian 7 ngày nuôi trong môi trường chứa $422 \mu \mathrm{g} \mathrm{Cr} L^{-1}$. Kết quả cho thấy Cr tại nồng độ lên tới $1.078 \mu \mathrm{g} \mathrm{L}^{-1}$ không kìm hãm sư phát triển và tốc độ sinh trương của P. mucicola. Tương tư, tại nồng độ $224 \mu \mathrm{g}$ Cr $L^{-1}$ không có bất kì ảnh hưởng tiêu cực đến sự phát triển của P. duplex. Loài tảo lam P. mucicola có thể làm giảm $71 \%$ hàm luợng Cr trong môi trường thí nghiệm, vì vây được xem là úng viên sáng giá cho quá trình xử lý môi trường ô nhiễm kim loại bằng thực vật. Theo hiểu biết của nhóm tác giả, đây là nghiên cưu đầu tiên về đáp ưng và hấp thu Cr bởi những vi tảo nước ngọt có nguồn gốc tù̀ Việt Nam.

Keywords: microalgae, chromium, growth rate, metal uptake, phytoremediation

\section{Introduction}

Phytoplankton including algae and cyanobacteria are worldwide distribution and very common organisms in aquatic water bodies. Being primary producers, microalgae play a key role in aquatic ecosystems such as oxygen liberation to the air and vital parts of the geo-bio- chemical cycle allowing the flow of matter and energy become continuously (Horne and Goldman, 1994).

Many trace metals are known as the essential elements for living things (Andersen, 1981). However, in recent years, the common presence of trace metals (e.g. cadmium $(\mathrm{Cd})$, chromium $(\mathrm{Cr})$, cobalt $(\mathrm{Co})$, copper $(\mathrm{Cu})$, lead $(\mathrm{Pb}))$ with 
high concentrations in the aquatic and soil environment because the anthropogenic activities have become a potential risk for unintended adverse health impacts to both humans and non-target wildlife (Soares and Soares, 2012. Among trace metals, $\mathrm{Cr}$ is widely utilised in tanning factories, steel works, industrial electro-planting, wood preservation and fertilizers (Babchi et al., 2002). It has been found that $\mathrm{Cr}$ concentration in wastewater could reach $800 \mathrm{mg} \mathrm{L}^{-1}$ (Plugaru et al., 2016). There are few studies on toxicity of $\mathrm{Cr}$ compared to those of other metals (Wong and Trevors, 1988; Wallen, 1995). Chromium can exist in oxidation state ranging from $\mathrm{Cr}^{2+}$ to $\mathrm{Cr}^{6+}$, however, the trivalent state $\mathrm{Cr}^{3+}$ and the hexavalent state $\mathrm{Cr}^{6+}$ are the more readily assimilated forms and most toxic (Schroll, 1978; Towill et al., 1978). Previous studies focused on the toxicity of $\mathrm{Cr}$ on animals, especially fish (Mearns et al., 1976; Svecevicius, 2006; Rani et al., 2011; Josefina et al., 2011. Besides, detrimental effects of this contaminant on algae have also been investigated showing that $\mathrm{Cr}$ affected the algal photosynthesis and growth (Plugaru et al., 2016; Wium-Andersen, 1974; Fasulo et al., 1983; Horcsick et al., 2006).

Recently many researchers have considered using microalgae to remove some toxic substances including trace metals by accumulation, adsorption and metabolism (Muhaemin, 2004; Nacorda et al., 2007; Lim et al., 2010; Priyadarshani et al., 2011). There have been numerous investigations demonstrating high efficiency of algal application for environmental remediation via the high bioaccumulation potential of trace metals such as $\mathrm{Pb}, \mathrm{Cd}$, $\mathrm{Hg}, \mathrm{Cu}$ (Costa and Franca, 2003; Chen et al., 2005; Chojnacka et al., 2005; Lamaiet al., 2005; Al-Rub et al., 2006; Lim et al., 2010; Miranda et al., 2012). Regarding Cr, algae in water bodies have ability to strongly adsorb this pollutant, for example, Doshi et al. (2008) measured the adsorption of $\mathrm{Cr}^{3+}$ and $\mathrm{Cr}^{6+}$ on two algal species Cladophora sp. and Spirulina sp. The authors found that Cladophora sp. adsorbed $347 \mathrm{mg} \mathrm{g}^{-1} \mathrm{Cr}^{3+}$ and $168 \mathrm{mg} \mathrm{g}^{-1} \mathrm{Cr}^{6+}$, the other species took up to $306 \mathrm{mg} \mathrm{g}^{-1} \mathrm{Cr}^{3+}$ and $202 \mathrm{mg}$ $\mathrm{g}^{-1} \mathrm{Cr}^{6+}$ (Doshi et al., 2008).

In Vietnam, researches on the potential application of freshwater algae from Vietnam have been conducted e.g. lipid production capacity (Nguyen et al., 2013; Phan et al., 2013), and metal exposures (Dao et al., 2017). However, the information on metal uptake potential of algal is scarce. Therefore, the aims of this study are to assess (i) the growth of two micro-algal species, Pediastrum duplex and Pseudanabaena mucicola, from Vietnam upon exposure to chromium and (ii) the chromium absorption capacity of $P$. mucicola in the laboratory conditions.

\section{Materials and methods}

The microalgae Pediastrum duplex Meyen and Pseudanabaena mucicola (Naumann et Huber-Pestalozzi) Schwabe (Fig. 1), isolated from Saigon River and Tri An Reservoir in Southern Vietnam, respectively, were used as the test organisms. These species were cultivated in Z8 medium (Kotai, 1972) in the laboratory conditions of $27 \pm$ $1{ }^{\circ} \mathrm{C}$, light intensity of around 3,000 Lux, light: dark cycle of 12h:12h (Dao et al., 2010)

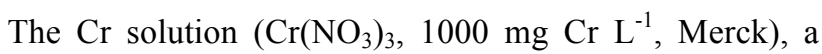
standard for ICP/MS analysis (trace analysis), was used as stock solution for the experiment with algae. Before being used for the tests, the test solutions (Z8, and Z8 added with $\mathrm{Cr}$ ) were filtered through a filter with the pore size of $0.2 \mu \mathrm{m}$ (Millipore, England) to prevent any bacterial contamination.

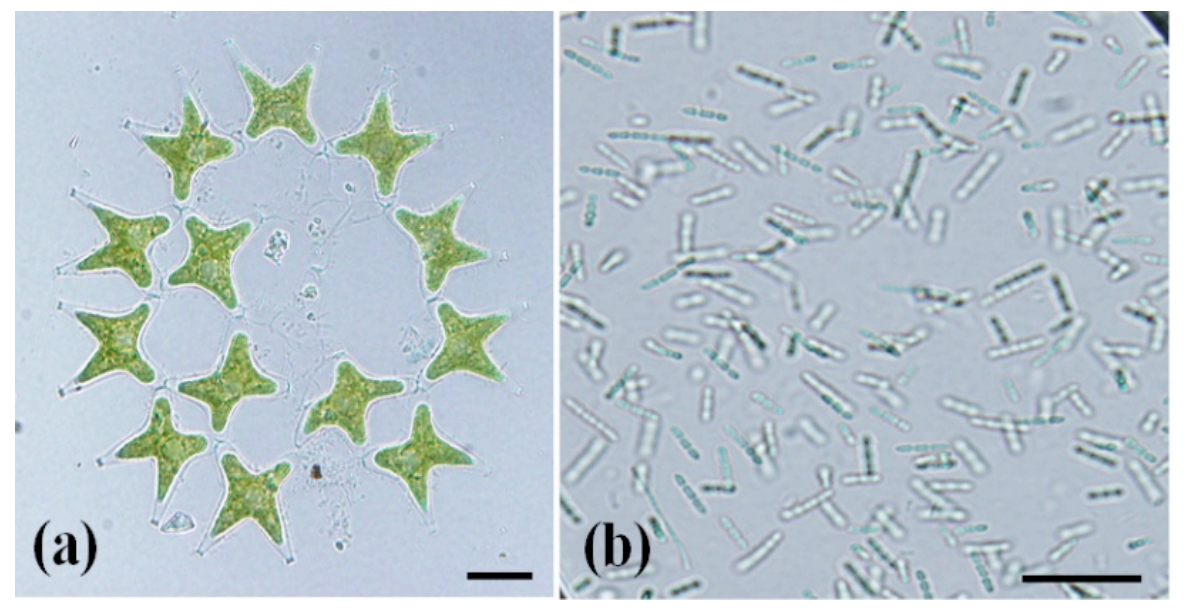

Figure 1. The two microalgal species used for experiments Pediastrum duplex (a), and Pseudanabaena mucicola (b). Scale bars $=20 \mu \mathrm{m}$

In the experiment on the growth of microalgae upon exposure to $\mathrm{Cr}$, the two algal species were separately incubated in Z8 medium containing three different $\mathrm{Cr}$ concentrations (Table 1). In metal exposures, either $P$. duplex or $P$. mucicola was incubated in a $250 \mathrm{~mL}$ flask containing $150 \mathrm{~mL}$ of test solution. The incubation in which test solution was not added with $\mathrm{Cr}$ was run as the control. Three replicates were prepared for each exposure $\mathrm{Mu}-$ haemin, 2004). The $P$. mucicola densities at the start of the experiment were $120( \pm 6) \times 10^{4}$ and $131( \pm 32) \times 10^{4}$ trichomes $\mathrm{mL}^{-1}$ in the control and $\mathrm{Cr}$ exposures, respectively. The $P$. duplex densities at the start of the experiment were $6( \pm 0.4) \times 10^{4}$ and $7.1( \pm 0.7) \times 10^{4}$ colonies $\mathrm{mL}^{-1}$ in the control and $\mathrm{Cr}$ exposures, respectively. At the start of the experiment, a sub-sample from each test solution was filtered through $0.45 \mu \mathrm{m}$ filter (Sartorius, Ger- 
many) and acidified with saturated $\mathrm{HNO}_{3}$ (Merck). Then $\mathrm{Cr}$ concentrations in the sub-samples were determined by the Electrothermal Atomic Absorption Spectrometric Method (PinAACle 900Z, Perkin Elmer, USA; APHA, 2012). The experiments on the algal growth were run over a period of 14 days. At the beginning of the experiment and every two days, $1 \mathrm{~mL}$ of algal solution from the test flasks was taken out, fixed with Lugol solution and counted with a Sedgewick Rafter counting chamber on a microscope (Sournia, 1978).

In the experiment on metal uptake by microalgae, the alga $P$. mucicola was incubated in $1 \mathrm{~L}$ flasks containing 500 $\mathrm{mL}$ of test solution in the laboratory conditions as mentioned above. The control test solution included $\mathrm{Z8}$ medium containing $\mathrm{Cr}$ at the concentration of $566 \mu \mathrm{g} \mathrm{\textrm {L } ^ { - 1 }}$ (without alga in the control) whereas the exposure, 3 replicates, was prepared with $\mathrm{Z8}$ medium containing the alga and $\mathrm{Cr}$ at the concentration of $422 \mu \mathrm{g} \mathrm{\textrm {L } ^ { - 1 }}$. This experiment lasted for 7 days. When the experiment termi- nated, sub-sample $(50 \mathrm{~mL})$ of the test solutions (both control and exposure) were filtered $(0.45 \mu \mathrm{g}$ pore size filter, Sartorius), acidified with $\mathrm{HNO}_{3}$ (Merck) then metallic $(\mathrm{Cr})$ characterized as mentioned above (Perkin Elmer, USA).

The hardness, $\mathrm{pH}$, alkalinity and dissolved organic carbon of the test solutions were analyzed (APHA, 2012) to characterize the basic characteristics of the experiments and the conditions for algal growth.

The growth rate of microalgae $(\mathrm{R})$ was calculated according to Lobban et al. (1988) with the equation of $\mathrm{R}=\left(\ln \mathrm{X}_{2}\right.$ $\left.-\ln \mathrm{X}_{1}\right) /\left(\mathrm{t}_{2}-\mathrm{t}_{1}\right)$; where $\mathrm{X}_{1}$ and $\mathrm{X}_{2}$ are algal densities at time $t_{1}$ and $t_{2}$. Metal uptake ratio was calculated as $(\%)=$ $100 \times\left(M_{1}-M_{2}\right) / M 1$; where M1 and M2 are metal concentrations at the first day and the end of the test (Lobban et al., 1988). Kruskal-Wallis test (Sigma Plot 12.0) was applied for calculation the significant difference of the growth rate between control and exposures.

Table 1. Chromium concentrations in the test solutions with microalgae. UDL, under detection level of the equipment, $1 \mu \mathrm{g} \mathrm{L}^{-1}$.

Chromium concentrations $\left(\mu \mathrm{g} \mathrm{L}^{-1}\right)$

\begin{tabular}{lc}
\hline Test species & Control \\
Pediastrum duplex & UDL \\
Pseudanabaena mucicola & UDL
\end{tabular}

\section{Results and discussion}

The $\mathrm{pH}$ of the test solutions ranged from $6.1-8.6$. The hardness and the alkalinity of the solutions valued from $28-35 \mathrm{mg} \mathrm{CaCO}_{3} \mathrm{~L}^{-1}$ and $8-8.5 \mathrm{mg} \mathrm{CaCO}_{3} \mathrm{~L}^{-1}$, respectively. The dissolved organic carbon (DOC) concentration of the $\mathrm{Z} 8$ medium was $30.5 \mathrm{mg} \mathrm{L}^{-1}$. Toxicity of metals to aquatic organisms is regulated by some environmental factors such as $\mathrm{pH}$, alkalinity, hardness and DOC in water. The increase of $\mathrm{pH}$, DOC concentration and the decrease of hardness in the test medium resulted in the decrease of metal bioavailability consequently toxicity decrease to aquatic organisms (Paulauskis and Winner, 1988; Naddy et al., 2015; Taylor et al., 2016). The alkalinity and hardness of this study could be classified as soft water (Villavicencio et al., 2005; Naddy et al., 2015) which enhanced the bioavailability of $\mathrm{Cr}$ in the test medium. These physical and chemical characteristics revealed suitable conditions for development of microalgae (e.g. $\mathrm{pH})$ and the high bioavailability of $\mathrm{Cr}$ to the microalgae (alkalinity and hardness).

\subsection{Development of microalgae under expo- sure to chromium}

The density of $P$. mucicola in control medium and $\mathrm{Cr}$ medium linearly increased during the time of incubation (Fig. 2a). After 14 days of experiment, the density of $P$. mucicola in the control medium (density of $1,417 \times 10^{4}$ trichomes $\mathrm{mL}^{-1}$ ) was 11.8 times and that in $\mathrm{Cr}$ medium (densities of $1,406-2,224 \times 10^{4}$ trichomes $\mathrm{mL}^{-1}$ ) was $10.2-16.4$ times higher than the density at the start of the test. However, there was no significant difference be-

$\begin{array}{ccc}\text { Exposure 1 } & \text { Exposure 2 } & \text { Exposure 3 } \\ 8 & 224 & 1,936 \\ 6 & 118 & 1,078\end{array}$

tween the $P$. mucicola density increase in control and $\mathrm{Cr}$ exposure conditions ( $\mathrm{p}>0.05$, Kruskal-Wallis test).

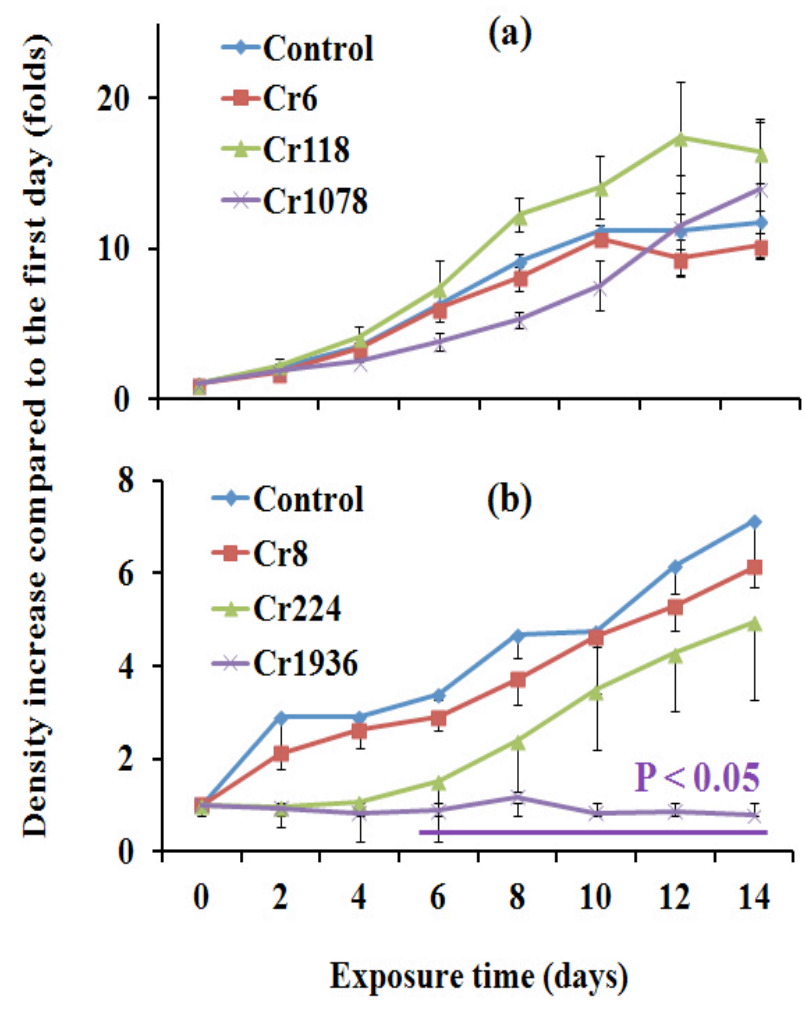

Figure 2. Development of Pseudanabaena mucicola (a) and Pediastrum duplex (b) during the exposure to chromium. Significant different between Cr1936 exposure in $P$. duplex and control $(p<0.05)$ was tested by Kruskal-Wallis 
In the test with $P$. duplex, by the end of experiment, the density increased in the control medium $\left(42.6 \times 10^{4}\right.$ colonies $\left.\mathrm{mL}^{-1}\right)$ and two lower $\mathrm{Cr}$ medium exposures $(\mathrm{Cr} 8$ and Cr224; densities of $36.2-41.2 \times 10^{4}$ colonies $\mathrm{mL}^{-1}$ ) was slowly raised, reaching around 5-7 times higher than that at the start of the test. However, that in exposure to Cr1936 was inhibited and decreased to 0.7 times (or $70 \%$ with density of $5.2 \times 10^{4}$ colonies $\mathrm{mL}^{-1}$ ) compared to the start. Consequently, the $P$. duplex density increase of Cr1936 was significantly different from that of the control from day 6 to the end of the experiment (Fig. 2b).

Wong and Chang (1991) reported that $\mathrm{Cr}$ at the concentrations of $250 \mu \mathrm{g} \mathrm{L}^{-1}$ did not cause an inhibitory on the growth of Chlorella pyrenoidosa. However, the authors found the severe inhibition of $1,000 \mu \mathrm{g} \mathrm{Cr} \mathrm{L}^{-1}$ on the $C$. pyrenoidosa growth (Wong and Chang, 1991). However, the green alga Pseudokirchneriella subcapitata was more sensitive to $\mathrm{Cr}$ than the cyanobacterium Microcystis aeruginosa (Rodgher et al., 2012). Besides, two strains of Chlorella vulgaris showed different resistance to $\mathrm{Cr}$ (Nacorda et al., 2007). Hence, responses of algae to metals should be species and strain specific

\subsection{Growth rate of microalgae under expo- sure to chromium}

During 14 days of development, the average growth rate of $P$. mucicola in control medium and $\mathrm{Cr}$ medium was similar, ranging from $0.18-0.22$ folds day ${ }^{-1}$ (Fig. 3a). No significant difference was found between the control medium and the $\mathrm{Cr}$ exposures. Similarly, in the experiment with $P$. duplex, there was no statistical difference ( $\mathrm{p}$ $>0.05$ by Kruskal-Wallis test) between the control and the exposures, $\mathrm{Cr} 8$ and $\mathrm{Cr} 224$. The average growth rate values of these treatments were from $0.14-0.17$ (Fig. $3 b)$. However, upon exposure to the highest $\mathrm{Cr}$ concentration the growth of $P$. duplex was inhibited. The growth rate of $P$. duplex in the exposure Cr1936 during the experiment was -0.02 folds per day (Fig. 3b).

The metal $\mathrm{Cr}$ is a micronutrient that is essential for metabolisms in cells of plants. Growth of algae was not inhibited (Wong and Chang, 1991) at the Cr concentration of $250 \mu \mathrm{g} \mathrm{L}^{-1}$. However, $\mathrm{Cr}$ concentrations exceeded 500 $\mu \mathrm{g} \mathrm{L}^{-1}$ inhibited photosynthesis of $C$. pyrenoidosa (Wong and Chang, 1991) and those from $1,500 \mu \mathrm{g} \mathrm{L}^{-1}$ or higher $\left(9,000 \mu \mathrm{g} \mathrm{L}^{-1}\right)$ negatively affected the cell membranes of living things leading to the increase of their permeability consequently inhibit growth (Fasulo et al., 1983). This helped to explain the adverse effect of $\mathrm{Cr}$ on $P$. duplex in current study (Fig. 3b). Differently, Horcsick et al. (2006) found the negative effects of $1,000 \mu \mathrm{g} \mathrm{Cr} \mathrm{L}^{-1}$ on cell density growth of $C$. pyrenoidosa within $72 \mathrm{~h}$ of exposure (Horcsick et al., 2006). On the contrary, Plugaru et al. (2016) exposed another strain of $C$. pyrenoidosa to $\mathrm{Cr}$ at the concentrations of $1-5 \mathrm{mg} \mathrm{L}^{-1}$ for $72 \mathrm{~h}$ and recorded no adverse effects of $\mathrm{Cr}$ on growth of the alga (Plugaru et al., 2016). However, the later study ran the experiment without replicates (Plugaru et al., 2016) therefore their results lacked of statistical analysis consequently weak convince to readers. Our study showed a long time of exposure (14 days) to the metal whereas previous studies conducted their experiments in a shorter time, from $3-6$ days (Plugaru et al., 2016; Horcsick et al., 2006) or up to 12 days (Nacorda et al., 2007). Nacorda et al. (2007) observed the decrease of algal growth with $\mathrm{Cr}$ concentration dependence. Growth rate of $C$. vulgaris exposed to 1 $\mathrm{mg} \mathrm{Cr} \mathrm{L}{ }^{-1}$ and $2 \mathrm{mg} \mathrm{Cr} \mathrm{L}^{-1}$ was $70 \%$ and $50 \%$, respectively, compared to that of the control. Hence, this again indicated that the species P. mucicola is less sensitive than the two green algae $C$. pyrenoidosa and $C$. vulgaris. Besides, $P$. duplex in our study is more sensitive than $C$. vulgaris in the investigation of Nacorda et al. (2007). Our finding suggested that $P$. mucicola is a good candidate for

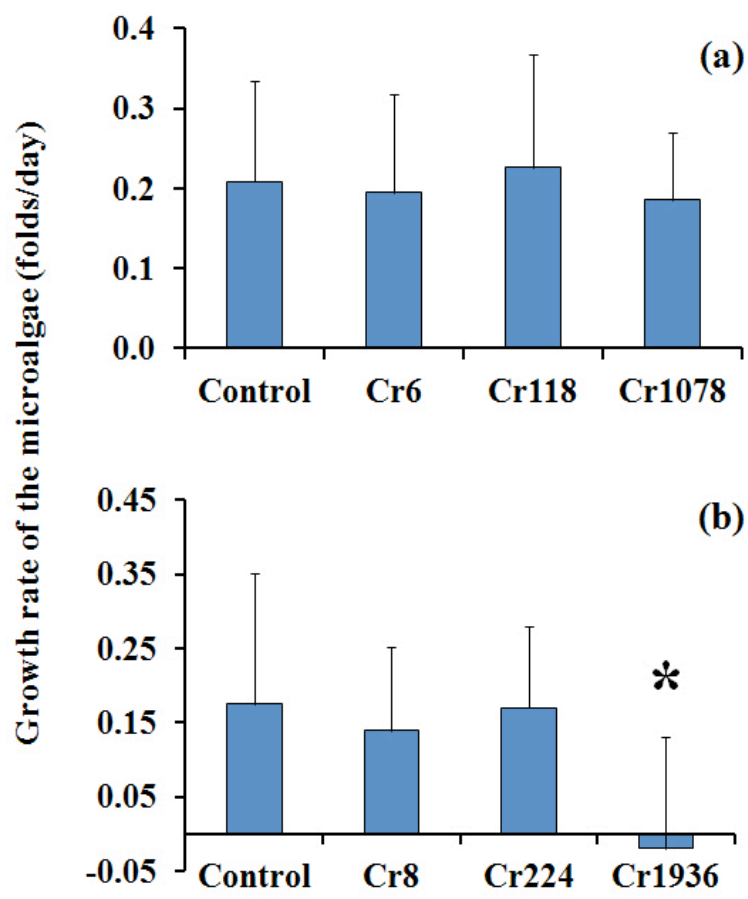

Cr removal investigations.

Figure 3. Growth rate of Pseudanabaena mucicola (a) and Pediastrum duplex (b) during the exposure to chromium. The asterisk indicates the significant different $(\mathrm{p}<0.05)$ between control and $\mathrm{Cr}$ exposure by Kruskal-Wallis

\subsection{Chromium uptake by the alga Pseudana- baena mucicola}

The mean concentrations of $\mathrm{Cr}$ in the control ( $\mathrm{Z} 8$ medium and $\mathrm{Cr}$, without alga) and exposure ( $\mathrm{Z} 8$ medium and $\mathrm{Cr}$ and alga) ) after 7 days of incubation were $501 \mu \mathrm{g} \mathrm{L}^{-1}$ and $73 \mu \mathrm{g} \mathrm{L}^{-1}$, respectively. The $\mathrm{Cr}$ absorbance of flask in the control was around $11 \%$ and that of both flask and alga in the exposure was $82 \%$. Hence the $\mathrm{Cr}$ uptake by $P$. $m u$ cicola in this study was $71 \%$. This record revealed a very high potential of $\mathrm{Cr}$ absorption of $P$. mucicola compared to the $\mathrm{Cr}$ absorption capacity of $C$. vulgaris, $21-28 \%$ (Nacorda et al., 2007). Though the previous study ran for 12 days and did not test the Cr uptake by C. vulgaris after 7 days, we believed that the absorption of $C$. vulgaris would not much higher than $28 \%$ after 7 days of incubation, because this green alga reached its stationary phase of growth at around 12 days (Nacorda et al., 2007). The much higher $\mathrm{Cr}$ absorption capacity of the cyanobacte- 
rium in our study should be related to the higher tolerance to $\mathrm{Cr}$ of $P$. mucicola than $C$. vulgaris. Therefore, we recommend the species $P$. mucicola as a very promised organism for $\mathrm{Cr}$ removal in $\mathrm{Cr}$ polluted water.

\section{Conclusion}

Two isolated freshwater microalgae from Vietnam were firstly used as the test organisms for $\mathrm{Cr}$ exposure and uptake in the laboratory conditions. The $\mathrm{Cr}$ at the concentration up to $1,078 \mu \mathrm{g} \mathrm{L}^{-1}$ slightly influenced on development and growth rate of the cyanobacterium $P$. mucicola. Similar responses of the green alga $P$. duplex were ob-

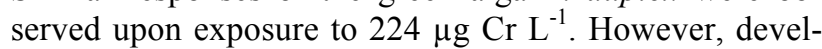
opment and growth rate of $P$. duplex were severely inhibited at $1,936 \mu \mathrm{g} \mathrm{Cr} \mathrm{L}^{-1}$. In the uptake and absorption test, $P$. mucicola could reduce up to $71 \%$ of dissolved $\mathrm{Cr}$ in water. This cyanobacterium showed a good candidate for phytoremediation in term of metal pollution in water bodies. Further investigations on the effects of metal mixture on microalgae and metal removal by algae are highly suggested.

Acknowledgement: This research is funded by Hochiminh City University of Technology - VNU-HCM under the granted project number SVOISP-2017MT\&TN-14

\section{References}

[1] Al-Rub F.A.A., El-Naas M.H., Ashour I., Marzouqi M.A. (2006), Biosorption of copper on Chlorella vulgaris from single, binary and ternary metal aqueous solutions. Process Biochemistry 41, 457-464.

[2] Anderson, R.A. (1981). Nutritional role of chromium. Science of Total Environment 17, 13-29

[3] APHA (2012). Standard methods for the examination of water and wastewater, 22nd Edition, American Public Health Association, American Water Works Association and Water Environment Federation, Washington, DC.

[4] Bagchi, D., Stohs, S.J., Downs, M., Bagchi, M., Preuss, H.G. (2002). Cytotoxicity and oxidative mechanisms of different forms of chromium. Toxicology $180(1), 5-22$.

[5] Chen, J.Z., Tao, X.C., Xu, J., Zhang, T., Liu, Z.L. (2005). Biosorption of lead, cadmium and mercury by immobilized Microcystis aeruginosa in a column. Process Biochemistry 40 (12), 3675-3679.

[6] Chojnacka, K., Chojnacka, A., Gorecka, H. (2005). Biosorption of $\mathrm{Cr}^{3+}, \mathrm{Cd}^{2+}$ and $\mathrm{Cu}^{2+}$ ions by bluegreen algae Spirulina sp.: kinetics, equilibrium and the mechanism of the process. Chemosphere 59, 7584.

[7] Costa, A.C.A., Franca, F.P. (2003). Cadmium Interaction with microalgal cells, cyanobacterial cells, and seaweeds: toxicology and biotechnological potential for wastewater treatment. Marine Biotechnology $5,149-156$.
[8] Dao, T.S., Cronberg, G., Nimptsch, J., Do-Hong, L.C., Wiegand, C. (2010). Toxic cyanobacteria from Tri An Reservoir, Vietnam. Nova Hedwigia 90, 433448.

[9] Dao, T.S., Vo, M.T., Vo, T.M.C. (2017). Effects of copper and chromium on the growth of micro green alga Scenedesmus acuminatus var. bieratus Reinsch. Proceeding of the 7 th national scientific conference on ecology and biological resources, 1898-1904.

[10] Doshi, H., Seth, C., Ray, A., Kothari, I.L. (2008). Bioaccumulation of heavy metals by green algae. Current Microbiology 56(3), 246-55.

[11] Fasulo, M.P., Bassi, M. Donni, A. (1983). Cytotoxic effects of hexavalent chromium in Euglena gracilis. II. Physiological and ultrastructure studies. Protoplasma 114, 35-43.

[12] Horcsick, Z., Olah, V., Balogh, A., Meszaros, I., Simon, L., Lakatos, G. (2006). Effect of chromium(VI) on growth, element and photosynthetic pigment composition of Chlorella pyrenoidosa. Acta Biologica Szegediensis. 50(1-2), 19-23.

[13] Horne, A.J., Goldman, C.R. (1994). Limnology. McGraw-Hill Inc., 571 pp.

[14] Josefina, V.C., Sonia, S., Marcelo, L.L. (2011). Acute toxicity of chromium on Cnesterodon decemmaculatus (Pisces: Poeciliidae) Theoria, 20(1), 8188.

[15] Kotai J. (1972). Instructions for preparation of modified nutrient solution Z8 for algae. Norwegian Institute for Water research Oslo B-11/69, 1-5.

[16] Lamai, C., Kruatrachue, M., Pokethitiyook, P., Upatham, E.S., Soonthornsarathool, V. (2005). Toxicity and accumulation of lead and cadmium in the filamentous green alga Cladophora fracta (O.F. Muller ex Vahl) Kutzing: A Laboratory Study. Science Asia 31, 121-127.

[17] Lim, S.I., Chu, W.L., Phang, S.M. (2010). Use of Chlorella vulgaris for bioremediation of textile wastewater. Bioresource Technology 101, 73147322 .

[18] Lobban, C.S., Chapman, D.J., Kremer, B.P. (1988). Experimental phycology - a laboratory mannual. Cambridge University Press.

[19] Mearns, A.J., Oshida, P.S., Sherwood, M.J., Young, D.R., Reish, D.J. (1976). Chromium effects on coastal organismsm. Water Pollution Control Federation 8, 1929-1939.

[20] Miranda, J., Krishnakumar, G., Gonsalves, R. (2012), $\mathrm{Cr}^{6+}$ bioremediation efficiency of Oscillatoria laete-virens (Crouan and Crouan) Gomont and Oscillatoria trichoides Szafer: kinetics and equilibrium study. Journal of Applied Phycology 24,14391454.

[21] Muhaemin M. (2004). Toxicity and bioaccumulation of lead in Chlorella and Dunaliella. Journal of Coastal Development 8, 27-33. 
[22] Nacorda, J.O., Martinez-Goss, M.R., Torreta, N.K., Merca, F.E. (2007). Metal resistance and removal by two strains of the green alga, Chlorella vulgaris Beijerinck, isolated from Laguna de Bay, Philippines. Journal of Applied Phycology 19, 701-710.

[23] Naddy, R.B., Cohen, A.S., Stubblefield, W.A. (2015). The interactive toxicity of cadmium, copper, and zinc to Ceriodaphnia dubia and rainbow trout (Oncorhynchus mykiss). Environ. Toxicol. Chem. 34, 809-815.

[24] Nguyen, T.M.L., Nguyen, H.N.P., Huynh, H.H., Nguyen, T.T., Le, T.T.L., Doan, T.M.T., Pham, T.H., Le, T.M.P. (2013). Screening for microalgae strains containing lipid in some places in Southern Vietnam. Vietnam Journal of Biology 35(3), 306312.

[25] Paulauskis, J.D., Winner, R.W. (1988). Effects ofwater hardness and humic acid on zinc toxicity to Daphnia magna Straus. Aquat. Toxicol. 12, 273-290

[26] Phan, T.T.N., Le, P.N., Bui, B.T., Dao, T.S. (2013). First report on the lipid from some Vietnam microalgae. Journal of Science and Technology 51(5C), 371-375.

[27] Plugaru, S., Sarb, A., Horcsik, T.Z., Rusu, T. (2016). The effects of chromium on the growth of Chlorella pyrenoidosa algal cultures. Environmental Engineering 5, 6-9.

[28] Priyadarshani, I., Sahu, D., Rath, B. (2011), Microalgae bioremediation: current practices and perspectives. Journal of Biochemistry Technology 3(3), 299-304.

[29] Rani, M.J., John, M.M.C, Uthiralingam, M., Azhaguraj, R. (2011). Acute toxicity of mercury and chromium to Clarias atrachus (Linn). Bioresearch Bulletin 5, 368-372.

[30] Rodgher, S., Espindola, E.L.G., Simoes, F.C.F., Tonietto, A.E. (2012). Cadmium and chromium toxicity to Pseudokirchneriella subcapiata and Microcystis aeruginosa. Brazilian Archives of Biology and Technology 55, 161-169.

[31] Schroll, H. (1978). Determination of the absorption of $\mathrm{Cr}^{+6}$ and $\mathrm{Cr}^{+3}$ in an algal culture of Chlorella pyrenoidosa using 15Cr. Bull. Environ. Contam. Toxi- col. 20, 721-724.

[32] Soares, E.V., Soares, H.M. (2012). Bioremediation of industrial effluents containing heavy metals using brewing cells of Saccharomy cescerevisiae as a green technology: a review. Environ. Sci. Pollut. Res. 19, 1066-1083.

[33] Sournia A. (1978). Phytoplankton manual, UNESCO, UK. P.69-74, 251-260.

[34] Svecevicius, G. (2006). Acute toxicity of hexavalent chromium to European freshwater fish. Bull. Environ. Contam. Toxicol. 77, 741-747.

[35] Taylor, N.S., Kirwan, J.A., Johnson, C., Yan, N.D., Viant, M.R., Gunn, J.M., McGeer, J.C. (2016). Predicting chronic copper and nickel reproductive toxicity to Daphnia pulex-pulicaria from whole animal metabolic profiles. Environ. Pollut. 212, 325-329.

[36] Towill, L.E., Shriner, C.R., Drury, J.S., Hammons, A.S., Holleman, J.W. (1978). Reviews of the environmental effects of pollutants. III Chromium. EPA600/1-78-023. U.S. Environmental Protection Agency, Cincinnati, $\mathrm{OH}$.

[37] Villavicencio, G., Urrestarazu, P., Carvajal, C., De Schamphelaere, K.A.C., Janssen, C., Torres, J.C., Rodriguez, P.H. (2005). Biotic ligand model prediction of copper toxicity to daphnids in a range of natural waters in Chile. Environ. Toxicol. Chem. 24 (5), 1287-1299.

[38] Wallen, D.G. (1995). Adaption of the growth of the diatom Fragilaria crotonensis (Kitton) and the phytoplankton assemblage of Lake Erie to chromium toxicity. Internat. Assoc. Great Lake Res. 22(1), 5562 .

[39] Wium-Andersen, S. (1974). The effect of chromium on the photosynthesis and growth of diatoms and green algae. Physiol. Plant., 32, 308-310.

[40] Wong, P.K., Chang, L. (1991). Effects of copper, chromium and nickel on growth, photosynthesis and chlorophyll a synthesis of Chlorella pyrenoidosa 215. Environmental Pollution 72, 127-139.

[41] Wong, P.T.S., Trevors, J.T. (1988). Chromium toxicity to algae. In: J.D. Nriagu and E. Nieboer (Editors), Chromium in the Natural and Human Environments. Wiley, New York, 305-315. 